\title{
To Study the Effect of Auxin Concentrations (IBA and IAA) on Growth Performance of Stem Cutting of Hardwickia binata (Roxb.)
}

\author{
Pavani Ramavath*, Afaq Majid Wani and M. Shiva Kumar
}

Department of Forest Biology and Tree Improvement, College of Forestry, Sam Higginbottom University of Agriculture, Technology and Sciences, Prayagraj - 211007, Uttar Pradesh, India

*Corresponding author

\section{A B S T R A C T}

\section{Keywords}

Indole 3- Butyric Acid (IBA), Indole 3- Acetic Acid (IAA), Hardwickia binata Roxb, Auxins

\section{Article Info}

\section{Received:}

11 October 2021

Accepted:

05 November 2021

Available Online:

10 November 2021
The present studies on "Effect of Plant Growth Regulators on Growth Performance of Stem Cutting of Hardwickia binata Roxb" was carried out in the mist chamber of Institute of Forest Biodiversity, Dulapally, Kompally, Hyderabad, during JanuaryApril, 2021. The cuttings of Hardwickia binata Roxb were prepared from selected superior phenotypes from the surrounding environments of Kompally, Hyderabad. Hardwickia binata Roxb. is difficult to root and need auxin treatment and controlled environment to successful survival and rooting. The cuttings were treated with 0,200 , $500,1000,1500,2000 \mathrm{mg} / \mathrm{l}$ concentrations of IBA and IAA and planted in poly bags under mist chamber. The experiment was conducted in a completely randomized design. Analysis of variance was worked out to assess the variation in Hardwickia binata Roxb. for eight characters. Treatment with IBA at 2000mg was found to be the best treatment as it achieved maximum in survival percentage $(52.64 \%)$, shoot length $(31.92 \mathrm{~cm})$, rooting percentage $(81.69 \%)$, number of roots per cutting $(20.44)$ and root biomass $(6.32 \mathrm{~g})$ followed by treatment with IAA at $2000 \mathrm{mg} / \mathrm{l}$ (T10) achieved maximum. The performance increased with an increase in concentrations of both IBA and IAA. Among the two auxins treatments, IBA was found to be most effective, showed significantly higher values compared to IAA. It is possible to successfully multiply the Hardwickia binata Roxb. cuttings by treating with $2000 \mathrm{mg} / \mathrm{l}$ of IBA under controlled phyto-environmental condition. The study evolved an easy and efficient protocol for vegetative propagation of HardwickiabinataRoxb.via stem cuttings to establish clonal forestry.

\section{Introduction}

Hardwickia binata Roxb is a medium to large sized deciduous tree of Indian origin and it belongs to the family Leguminosae, subfamily
Caesalpinioideae (Luna, 1996). It is found growing naturally in semi-arid and arid regions of Central, Western and Southern India and is locally known as Anjan, Kamara and Aacha. Commercially in trade, it is called 
as Indian Black wood or Anjan. Out of India, it has been reported to grow in countries like Pakistan, Bangladesh, Cambodia, Indonesia, Laos, Myanmar, Malaysia, Nepal, Papua New Guinea, Philippines, Thailand and Vietnam (Kundu, 2011). The genus Hardwickia is a monotypic genus represented by only one species i.e., H. binata (Seetharam and Kotresha, 1998).

Forest plantations are increasingly needed to meet the growing demands for wood and its products across the world. According to a recent estimate of $\mathrm{FAO}$, the plantations occupy an area about 277.9 million hectares, which is about $6.95 \%$ of total global forest area (Payn et al., 2015).The application of plant growth regulators triggers adventitious root formation, bud break and survival of stem cuttings. Auxins promote rooting, which can be either naturally occurring within the plant (endogenous) or applied to the plant (exogenous) during vegetative propagation. Wani, et al., 2018 Several researches demonstrated that synthetic auxins like IBA and NAA were most effective rather than naturally occurring auxin IAA in induction of adventitious roots in cuttings (Swamy et al., 2002, Hartmann et al., 2011, Gehlot et al., 2014).

Plant growth regulators, play a vital role in improving the rooting of stem cuttings in Hardwickia binata Roxb. the maximum rooting percentage found to increase the establishment of cuttings in nurseries. Growth regulators such as auxins enhances percentage of success and number of roots in Hardwickia binata Roxb. cuttings. This would improve the vigour of freshly transplanted plant material in the field, thus reduces the rate of mortality of plants and helps to maintain adequate crop stand in the field. Hence there is an immense need to increase the area under Hardwickia binata Roxb. to meet the domestic as well as export market of greater importance. Hence, there is a need for standardizing the type and concentration of growth regulators for high success rate in stem cuttings of Hardwickia binata Roxb.

\section{Materials and Methods}

The cuttings of Hardwickia binata Roxb were prepared from selected superior phenotypes from the surrounding environs of forest college, Hyderabad. Plus trees were selected on the basis of their phenotypically superior stems and crown characteristics and their size and stature in the stand. One year old branch cuttings were taken from $25 \pm 5$-year-old selected trees during November-December and February-March. The leafless cuttings about $15 \pm 2.5 \mathrm{~cm}$ length and $1-2 \mathrm{~cm}$ in diameter having 4-5 buds were taken. The sharp Secateurs were used for preparation of cuttings. Cuttings were immediately placed in 100C water top regent desiccation before treatment.

Mature cuttings were brought to laboratory and treated with $0,200,500,1000,1500$ and $2000 \mathrm{mg} \mathrm{L}^{-1}$ concentrations of Indole 3Butyric Acid (IBA) and Indole 3- Acetic Acid (IAA). The different IBA and IAA concentrations were prepared by dissolving the appropriate amount of IBA and IAA in 5$10 \mathrm{ml}$ of methanol and volume gradually made up to $1000 \mathrm{ml}$ with distilled water. The care was taken to prevent the precipitation of IBA and IAA during the process of dilution. The IBA and IAA solutions were transferred separately in to ten containers for giving treatments. The cuttings were divided in to ten groups and each group contained 30 cuttings, which were dipped in these ten solutions. The basal cut ends up to $2.5-\mathrm{cm}$ of cuttings was dipped in following concentrations of IBA and IAA for 24 hours duration.

The rooting medium was prepared by mixing with equal proportions of well-drained soil, 
river sand and FYM in 1:1:1 ratio. The rooting medium was sterilized with $0.2 \%$ formalin and Carbendazim solution and subjected to solarization treatment for 10 days to prevent any attack from soil borne pathogens.

The sterilized rooting media was then filled in poly bags. The size of 20 poly bags varied from $15-20 \mathrm{~cm}$ in length and $6-18 \mathrm{~cm}$ in diameter. The Polythene bags were arranged in the mist chamber according to the design of experiment.

\section{Results and Discussion}

\section{Survival Percentage}

IBA concentrations survival percentage ranged from $21.23 \%$ to $52.64 \%$ with the general mean of $38.52 \%$ Table 1.Among all the treatments, IBA $2000 \mathrm{mg} / \mathrm{l}$ has maximum survival percentage $(52.64 \%)$ followed by IBA $1500 \mathrm{mg} / \mathrm{l}$ (47.37\%), whereas control showed minimum survival percentage (18.00\%) followed by IBA $200 \mathrm{ppm}$ $(21.23 \%)$. IBA treatment gave highest survival percentage on cuttings in Morus alba. The increase in percentage may be due to vigorous rooting induced by the growth regulator enabling the cutting to absorb more nutrient and thereby producing more survival (Stancato et al., (2003), Singh et al., (2014)).

\section{Shoot Length (cm)}

IBA $2000 \mathrm{mg} / \mathrm{l}$ has maximum shoot length $(31.92 \mathrm{~cm})$ followed by IBA $1500 \mathrm{mg} / \mathrm{l}(26.18$ $\mathrm{cm})$, whereas control showed minimum shoot length $(5.76 \mathrm{~cm})$ followed by IBA $200 \mathrm{ppm}$ $(6.78 \mathrm{~cm})$ Table 1 . The maximum shoot length with optimum IBA treatments might be ascribed to better root growth which augmented absorption and translocation of nutrients from soil which take active part in various plant metabolic processes (Mewar et al., 2016).

\section{Rooting percentage}

Among all the treatments, IAA $2000 \mathrm{mg} / \mathrm{l}$ has highest rooting percentage $(70.17 \%)$ followed by IBA $\mathrm{mg} / \mathrm{l}$ (43.36\%), whereas control showed minimum rooting percentage (10.73\%) followed by IAA $200 \mathrm{mg} / \mathrm{l}(15.83 \%)$ Table 1 . There is overwhelming evidence that auxins promote rooting, which can be either naturally occurring within the plant (endogenous) or applied to the plant (exogenous) during vegetative propagation (Gehlot et al., 2014, Mewar and Naithani, 2016).

\section{Number of roots per cutting}

In IBA concentrations number of roots per cutting ranges from 6.19 to 20.44 with the general mean of 12.60 Table 1. Among all the treatments, IBA $2000 \mathrm{mg} / \mathrm{l}$ has maximum number of roots per cutting (20.44) followed by IBA $1500 \mathrm{mg} / \mathrm{l}$ (18.27), whereas control showed minimum number of roots per cutting (6.11) followed by IBA 200 ppm (6.19). Exogenous application of auxin treatments especially IBA and NAA enhanced rooting proliferation and as well as root number in several species (Babaie et al., 2014, Siddique and Hussain, 2007).

\section{Root biomass}

The root biomass increased with an increase in concentrations of both IBA and IAA Table 1. However, there were no significant differences found between control and $200 \mathrm{mg} / \mathrm{l}, 500 \mathrm{mg} / \mathrm{l}$ and $1000 \mathrm{mg} / \mathrm{l}, 1000 \mathrm{mg} / \mathrm{l}$ and $1500 \mathrm{mg} / \mathrm{l}$ of treatments of IBA whereas control and 200 $\mathrm{mg} / \mathrm{l}, 500 \mathrm{mg} / \mathrm{l}$ and $1000 \mathrm{mg} / \mathrm{l}, 1500 \mathrm{mg} / \mathrm{l}$ and $2000 \mathrm{mg} / \mathrm{l}$ treatments of IAA. cuttings were more responsive to rooting with IBA treatments, which enhanced a greater number of roots and better root growth that ultimately contributed for higher root biomass (Ingle, 2008, Swamy et al., 2002). 
Table.1 Effect of different concentrations of IBA and IAA on different growth parameter of stem cuttings in Hardwickia binata

\begin{tabular}{|c|c|c|c|c|c|}
\hline $\begin{array}{c}\text { Treatment } \\
\text { combinations }\end{array}$ & $\begin{array}{c}\text { Survival } \\
\text { percentage }\end{array}$ & $\begin{array}{l}\text { Shoot Length } \\
\text { (60DAP) }\end{array}$ & Rooting \% & No. of roots/cutting & $\begin{array}{c}\text { Root } \\
\text { biomass }\end{array}$ \\
\hline Control & 18.00 & 3.11 & 10.73 & 6.11 & 1.96 \\
\hline $200 \mathrm{mg} \mathrm{L}^{-1} \mathrm{IBA}$ & 21.23 & 3.98 & 16.57 & 6.19 & 2.23 \\
\hline $500 \mathrm{mg} \mathrm{L}^{-1} \mathrm{IBA}$ & 27.56 & 8.35 & 23.24 & 7.69 & 3.49 \\
\hline $1000 \mathrm{mg} \mathrm{L}^{-1} \mathrm{IBA}$ & 43.79 & 11.58 & 29.17 & 10.43 & 4.72 \\
\hline $1500 \mathrm{mg} \mathrm{L}^{-1} \mathrm{IBA}$ & 47.37 & 15.49 & 61.34 & 18.27 & 5.31 \\
\hline $2000 \mathrm{mg} \mathrm{L}^{-1} \mathrm{IBA}$ & 52.64 & 20.16 & 81.69 & 20.44 & 6.32 \\
\hline $200 \mathrm{mg} \mathrm{L}^{-1} \mathbf{I A A}$ & 20.18 & 3.87 & 15.83 & 6.17 & 2.19 \\
\hline $500 \mathrm{mg} \mathrm{L}^{-1}$ IAA & 25.27 & 9.68 & 23.48 & 6.23 & 3.43 \\
\hline $1000 \mathrm{mg} \mathrm{L}^{-1} \mathrm{IAA}$ & 33.83 & 10.46 & 32.91 & 7.39 & 3.67 \\
\hline $1500 \mathrm{mg} \mathrm{L}^{-1}$ IAA & 41.42 & 15.37 & 43.36 & 9.12 & 4.76 \\
\hline $2000 \mathrm{mg} \mathrm{L}^{-1} \mathrm{IAA}$ & 48.01 & 15.55 & 70.17 & 10.55 & 5.68 \\
\hline F test & $\mathrm{S}$ & $S$ & $S$ & $\mathrm{~S}$ & NS \\
\hline $\operatorname{SEm}( \pm)$ & 0.15 & 0.08 & 0.03 & 0.08 & 0.11 \\
\hline $\mathrm{CD}(\mathrm{P}=\mathbf{0 . 0 5})$ & 0.45 & 0.25 & 0.07 & 0.25 & 0.34 \\
\hline
\end{tabular}

Fig.1 Effect of auxins application on the sprouting percentage of Hardwickia binata Roxb. Cuttings.

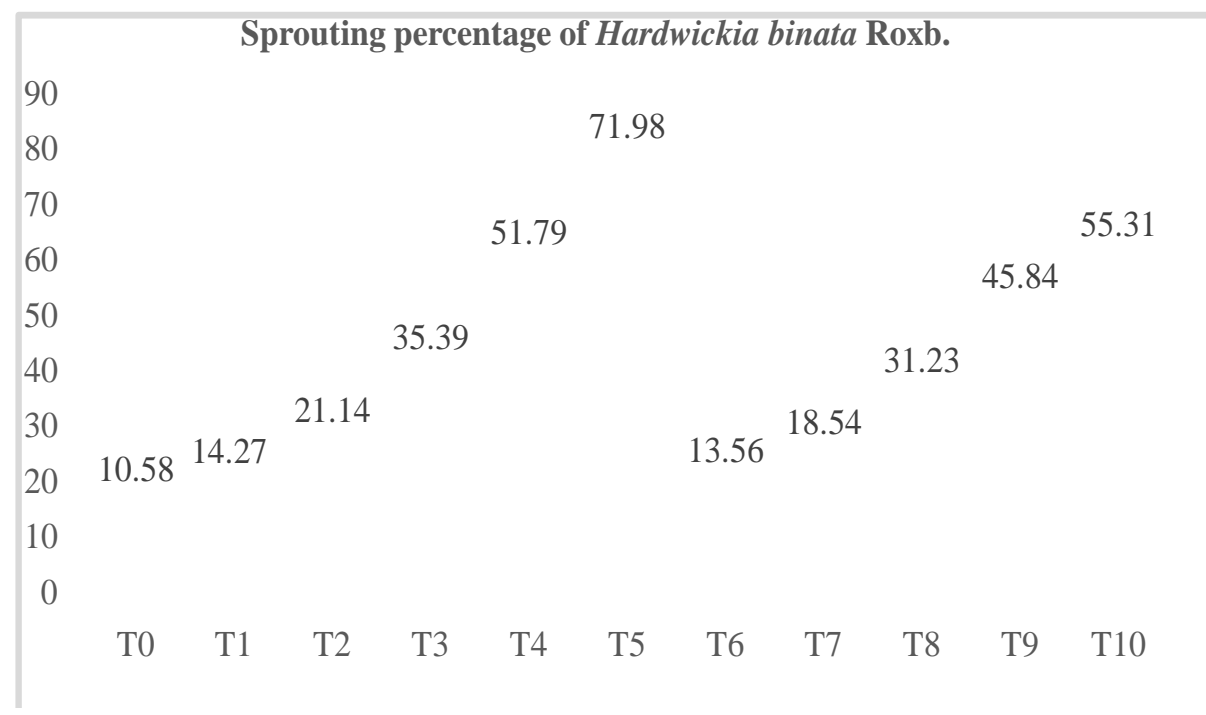


Fig.2 Effect of auxins application on the length of roots of Hardwickia binata Roxb. cuttings

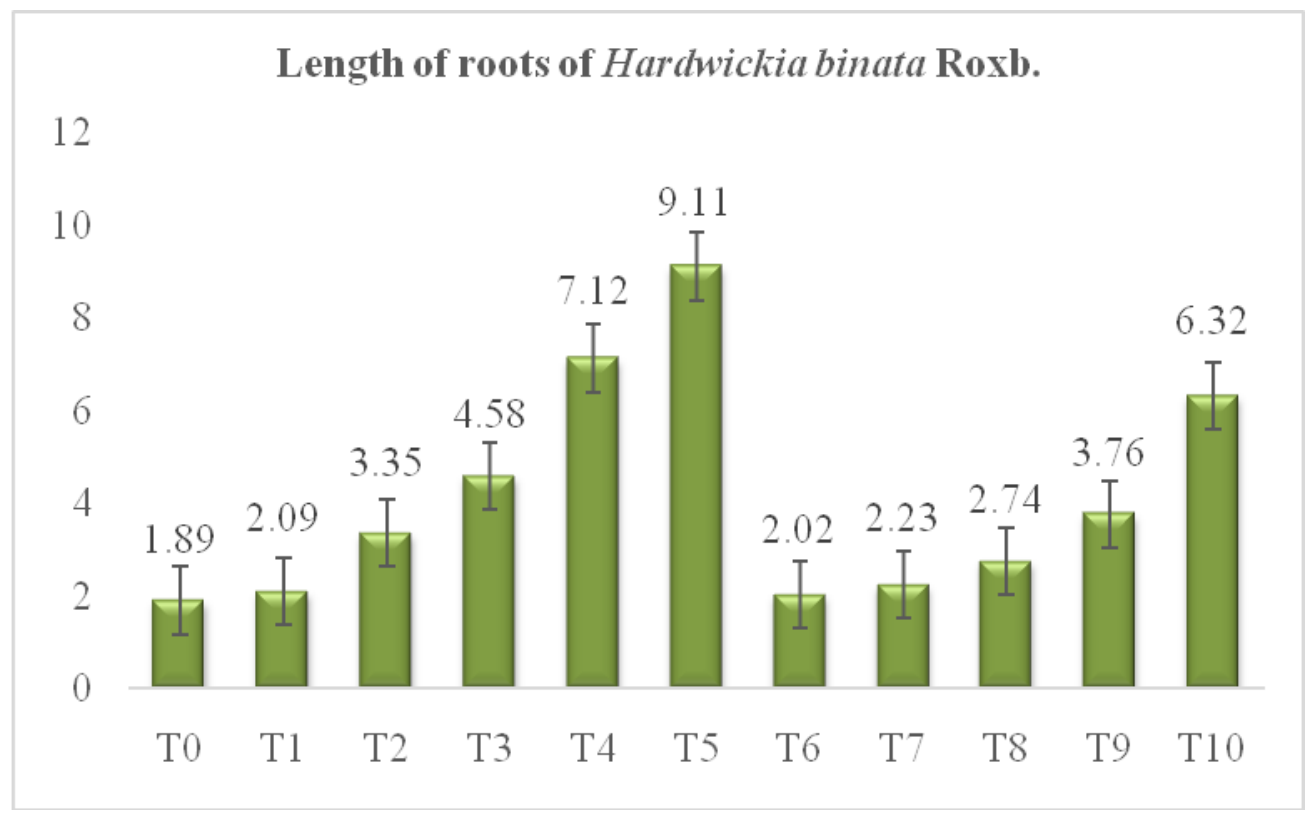

Fig.3 Effect of auxins application on the shoot biomass of Hardwickia binata Roxb. cuttings

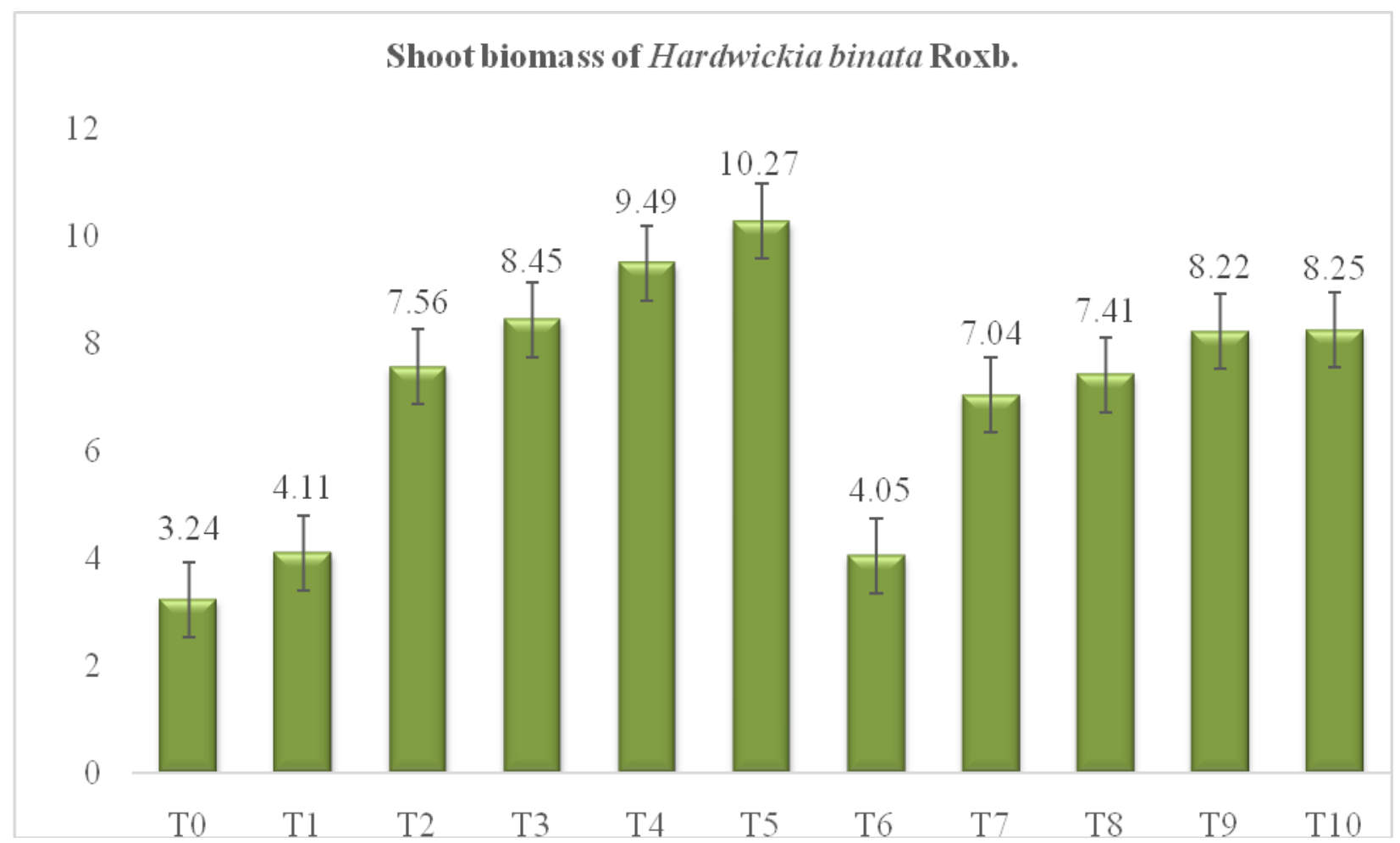


Plate.1 Comparison of rooting in stem cuttings of Hardwickia binata Roxb. under control, 200, 500 and $1000 \mathrm{mg} \mathrm{L}^{-1}$ of IBA
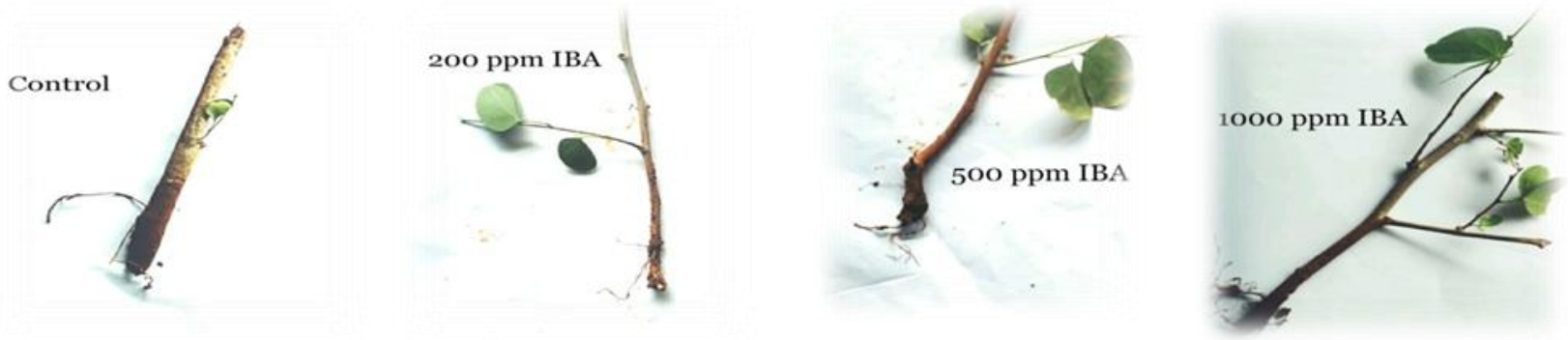

Plate.2 Comparison of rooting in stem cuttings of Hardwickia binata Roxb.under 500, 1000, 1500 and $2000 \mathrm{mg} \mathrm{L}^{-1}$ of IBA
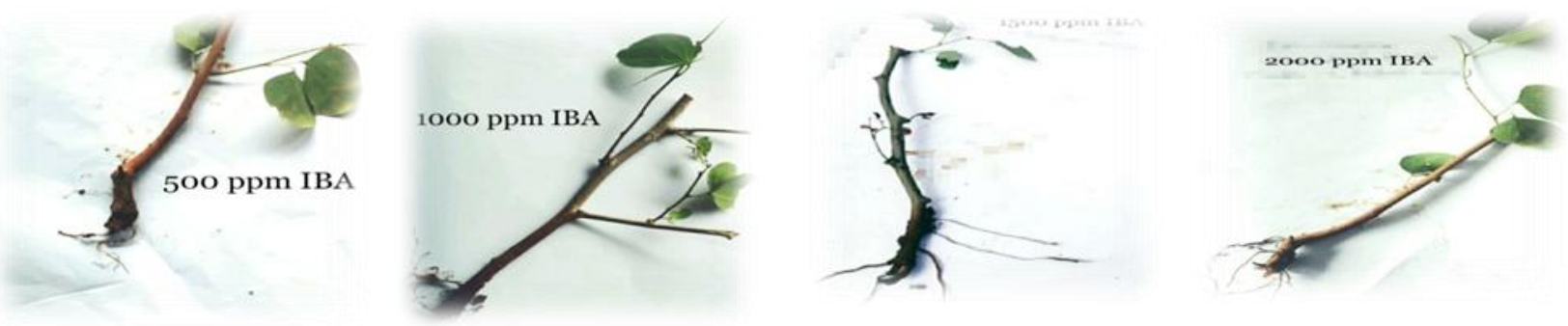

Plate.3 Comparison of rooting in stem cuttings of Hardwickia binata Roxb.under control, 200, 500 and $1000 \mathrm{mg} \mathrm{L}^{-1}$ of IAA.
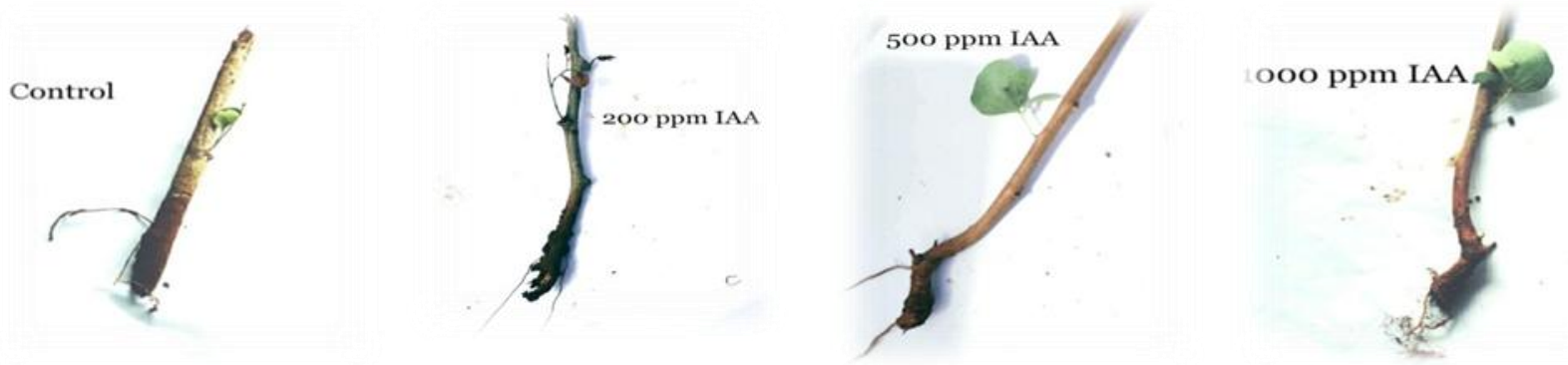

Plate.4 Comparison of rooting in stem cuttings of Hardwickia binata Roxb.under 500, 1000, 1500 and $2000 \mathrm{mg} \mathrm{L}^{-1}$ of IAA
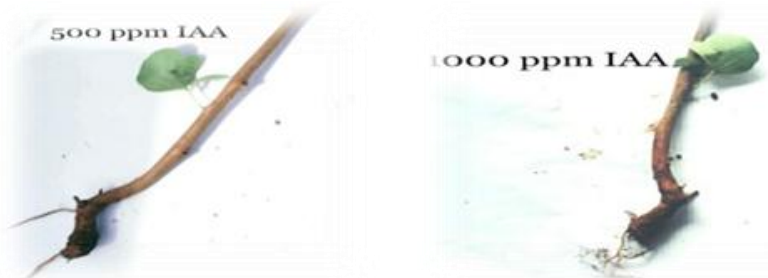

The results of the present study lead to the conclusion that Hardwickia binata Roxb. is difficult to root and need auxin treatment and controlled environment to successful survival
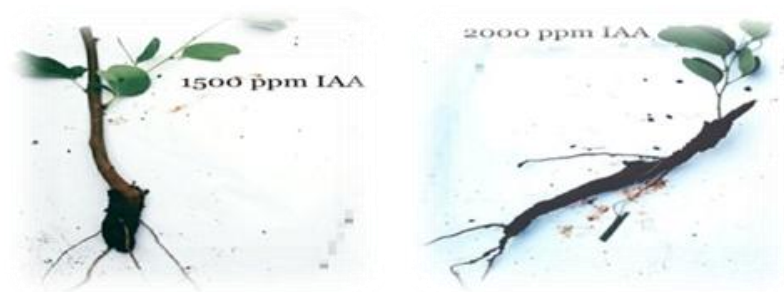

and rooting. The results revealed that IBA and IAA treatments significantly increased survival percentage, shoot length, sprouting percentage, rooting percentage, number of 
roots per cutting, length of roots, shoot biomass and root biomass. The performance increased with an increase in concentrations of both IBA and IAA. Among the two auxins treatments, IBA was found to be most effective, showed significantly higher values compared to IAA. The present study is limited to find out suitable concentrations of IBA and IAA on rooting for clonal multiplication of Hardwickia binata Roxb.

\section{References}

Babaie, H., Zarei, H., Nikde, K. and Firoozhai, M. N. 2014.Effect of different concentrations of IBA and time of taking cutting on rooting, growth and survival of Ficus binnendijkii 'amstel queen' cuttings. Notulae Sci. Bio., 6(2): 163-166.

Gehlot, A., Gupta, R. K., Tripathi, A., Arya, I. and Arya S. 2014.Vegetative propagation of Azadirachta indica: effect of auxin and rooting media on adventitious root induction in mini-cuttings. Adv. in For. Sci., 1(1): 106115.

Hartmann, H. T., Kester, D. E., Davies, F. T. Jr. and Geneve, R. L. 2011. Plant propagation: principles and practices, 8th edn. New York: Prentice-Hall, Sao Paulo, p. 915

Ingle, M R. 2008. Effect of growth regulators and environments on rooting of Stevia cuttings (Stevia rebaudiana Bertoni).MSc. Thesis.UnivAgriSciDharwad. P. 89

Luna R K. 1996. Plantation Trees. International Book Distributors, Dehradun.

Mewar, D. and Naithani, D C. 2016. Effect of different IBA concentrations and planting time on stem cuttings of wild fig (Ficus palmate forsk.). Plant Arc., 16(2): 959-962.

Kundu M and Schmidt L H. 2011. Hardwickia binata Roxb. Seed leaflet, No. 152. Forest and Landscape Denmark. University of Copenhagen.

Payn, T., Carnus, J M., Smith, P F., Kimberley, M., Kollert, W., Liu, S., Orazio, C., Rodriguez, L., Silva, L N. and Wingfield, M J. 2015. Changes in planted forests andfuture global implications. For.Eco.and Mang., 352: 57-67.

Seetharama Y N and Kotresha K. 1998.Foliar venation of some species of Bauhinia L. and Hardwickia binata Roxb. (Caesalpinioideae). Phytomorphology48(1): 51-59.

Swamy, S. L., Puri, S. and Singh, A. K. 2002. Effect of season and auxin (IBA and NAA) on rooting of juvenile and mature hard wood cuttings of Robinia psudoacacia Linn and Grewiaoptiva. New Forests, 23: 143-147.

Singh, K. K., Choudhary, T. and Kumar, A. 2014.Effect of Various Concentrations of IBA and NAA on the Rooting of Stem Cuttings of Mulberry (Morus alba L.) under Mist House Condition in Garhwal Hill Region. Ind. J. of Hill Farming 27(1):74-77.

Siddiqui, M I. and Hussain, S A. 2007. Effect of indole butyric acid and types of cutting on root initiation of Ficus hawaii.J. Agri., 23(4):919-925.

Wani Afaq Majid, Lipoksanen L Jamir and Prakash Rai. 2018. Effects of IBA, NAA and GA3 on rooting and morphological features of Ginkgo biloba Linn. stem cuttings. Journal of Pharmacogeny and Phytochemistry.7(3):1894-1896

\section{How to cite this article:}

Pavani Ramavath, Afaq Majid Wani and Shiva Kumar, M. 2021. To Study the Effect of Auxin Concentrations (IBA and IAA) on Growth Performance of Stem Cutting of Hardwickia binata (Roxb.). Int.J.Curr.Microbiol.App.Sci. 10(11): 243-249.

doi: https://doi.org/10.20546/ijcmas.2021.1011.028 